\title{
THE UNUSUAL SEPARATION OF CAPPADOCIAN REFECTORIES AND KITCHENS: AN ENIGMA OF ARCHITECTURAL HISTORY
}

\author{
Fatma Gül ÖZTÜRK
}

Received: 24.08.2011, Final Text: 06.12.2011

Keywords: Byzantine monasteries; Byzantine settlements; Byzantine Cappadocia; Cappadocia; rock-cut architecture; refectory monasteries; courtyard monasteries; courtyard complexes/ houses; Byzantine kitchens; Byzantine refectories; Middle Byzantine Period; trapezai; triclinia; refrigeria.

1.This is an extended and revised version of the paper that was presented at the Architectural History Conference/ Turkey I on October 20-22 2010 in the session Ancient/ Byzantine Period led by chair Numan Tuna.

2. Ousterhout $(1997 \mathrm{a}, 425)$ refers to Lucas (1712, 159-64). Lucas' report on Cappadocia has frequently been referenced by other scholars, including Kostof (1972, 32); Rodley $(1985,1)$; and Kalas $(2004,103)$.

3. For a critical approach to this "misinterpretation" see Ousterhout (1996a; 1997a; 2005a, 176-181; 2005b; 2010) and Kalas (2004; 2009a).

4. This is significant when one recalls the existence of documents for the Byzantine monastic centers outside Cappadocia (Rodley, 1985, 8-9); See also Kalas (2000; 2007b; 2009a) and Ousterhout (1996a; 1996b; 1997c; 2005b).

5. See also Ousterhout (2005a, 176-81, esp. 178 ); For a critical approach to the problems of identification of Byzantine monasteries in general, see Hill (1994).

6. For a general description of the Byzantine monastery, see Mango $(1976,198)$ and Johnson and Talbot (1991, 1391-2).

7. See Footnote 15 below.

\section{INTRODUCTION}

Paul Lucas, who visited Cappadocia in the early eighteenth century, claimed that the "strange carved spaces in the volcanic cones were the hermitages of Byzantine monks" (1) (2), which was echoed by the early European travelers and explorers that followed him, who also suggested that the harsh volcanic wilderness is likely to have attracted a large monastic community. Ever since, the region in central Anatolia, famous for its peculiar landscape and its carved structures, has retained the monastic identity with which it was initially stamped (Ousterhout, 1996a, 31) (3). Surprisingly, however, there is not a single document referring to Cappadocia in this sense, and it is unlikely that any will ever come to light (Rodley, 1985, 5, 237; Ousterhout, 2005a, 177) (4). As for physical evidence, unlike Western models, it is difficult to talk of a standard plan for a Byzantine monastery (Rodley, 1985, 240-4; Ousterhout, 1996a; 1997a) (5); and in the case of Cappadocia the idiosyncratic nature of the carved architecture makes it all the more difficult.

In general, for Byzantine monasteries, consistency in the appearance of some elements may still facilitate their identification as such. According to Svetlana Popović $(1998,281 ; 2007,48)$, for example, the presence of an enclosure wall, a church for communal worship and a refectory for the taking of communal meals would suggest a monastic establishment (6). Likewise, Spiro Kostof in his book Caves of God highlights two particular spaces within a carved complex, the church and the refectory, as being the main indicators of a monastic establishment in Cappadocia $(1972,51 ; 1989$, 51) (7). For the latter, this would mean the presence of a long rock-cut table, trapeza in Greek, and flanking benches; but interestingly Kostof's list of cave monasteries also includes complexes that contain neither a church nor a refectory. In 1985, Lyn Rodley (1985), in her book entitled Cave Monasteries of Byzantine Cappadocia, put forward a differentiation between the so-called "refectory monasteries" and "courtyard monasteries". Although this 
8. For a summary of the different approaches of scholars to Cappadocia, see Kalas (2004).

9. Indeed, the chapel was a common component of Byzantine houses (Mango, 1980, 82; Kuban, 1995, 30), and so does not provide concrete proof of monastic use (Ousterhout, 1997a, 428-30). See also Mathews and Daskalakis-Mathews (1997, 294-5, 298); and Kalas (2007b, 395; 2009a, 162).

10. See Footnote 15 below.

11. Mathews and Daskalakis-Mathews (1997); Ousterhout (1997a); Kalas (2000); Tütüncü (2008); Öztürk (2010); Rodley (1985) suggests secular use only for the complexes in Açıksaray, which she puts under a separate group. For other related works of Kalas and Ousterhout, see Bibliography.

12. See Footnote 11 above.

13. The term is borrowed from Ousterhout (2005a); See also Footnote 42 below.

14. One of the two points raised by Pierre Lucas $(2003,41)$ in the conclusion of his brief survey of more than twenty-five refectories in the vicinity of the Göreme Open Air Museum is that aside from one example, none featured kitchens. Lucas asks himself whether the lack of kitchens in the vicinity of refectories may have been a result of erosion, or whether there may have been outside fireplaces. Ousterhout $(2010,95)$ also mentions a single kitchen in the same area as the "one exception". The author of this paper could not relocate it; See also Footnote 75 below.

15. Mathews and Daskalakis-Mathews (1985, 298) claim that " $t]$ he refectory is the first and most important sign of a monastery". Ousterhout (1996a, 31) writes that "the presence of a refectory is a good indicator" for the monastic identification. Interestingly, the refectory is not one of the seven criteria listed by Hill (1994, 137-8) "for applying the label 'monastery' to a building".

Only recently scholars such as Ousterhout (2010) have begun to question the monastic function of the Cappadocian rock-cut refectories. In this respect, Kalas (2009c, 194) writes: "Nonetheless, the absence of a refectory at the Ala Kilise does not necessarily preclude the absence of a monastery, and there must be other criteria that could demonstrate a monastic identification for a church or a settlement." was an important step towards bringing scholarly order to the different perspectives on the numerous rock-cut cavities in the region, as the title of the book indicates, the prevalent monastic identity was still preserved (8). Rodley's differentiation -though without denying the existence of "some overlap" - was based on a simple rule: complexes with rock-cut table and benches can be defined as "refectory monasteries" (Figure 1, 2); while complexes with a more formal plan and "which are carefully carved to imitate built architecture" but without a rock-cut refectory could be referred to as "courtyard monasteries", despite the fact that not all of them contain a courtyard (Figure 3) (Rodley, 1985, esp. 9, 11). The examples she provided of both categories included only those complexes with an attached church or with a church in the close vicinity, but omitted many others of similar organization but lacking a church. Towards the end of the twentieth century, scholars conducting architectural surveys in the region began to question the monastic identity of Rodley's "courtyard type", claiming that an attached church alone does not necessarily imply a monastic identity (Ousterhout, 1997a, 422; 2005b, 214) (9). Accordingly, the lack of a refectory was considered as the main argument for the rather secular character of the courtyard type (Ousterhout, 2010, 95) (10), and they were accordingly re-classified as "courtyard complexes" or "courtyard houses" rather than monasteries. Consequently, aristocratic families with military connections residing in this border land of Byzantium were suggested as being the initial inhabitants of these complexes (11). Rodley (1985, 223-4) asserts that both the refectory and courtyard types were probably occupied for a short period, mainly during the eleventh century; and likewise, scholars speaking for the secular use of courtyard complexes date them to the tenth and eleventh centuries (12).

It is interesting to note that despite the absolute absence of any kind of rock-cut furniture for dining (Kalas, 2000, 89), the majority of so-called courtyard complexes contained spacious kitchens, recognizable from their huge conical, pyramidal or domical "chimney-vault" (13) and the occasional presence of carved hearths and niches in the surrounding walls (Figure 5-7). What is more noteworthy is that very few refectory monasteries included spaces that may be identified as kitchens (Figure 8), yet their contemporaneousness with the complexes is questionable (Rodley, 1985, 249; Kalas, 2000, 41; 2009d, 114-5) (14). Therefore, while supporting the argument related to the secular character of courtyard complexes, this paper sees the unusual separation of food preparation and communal dining as a challenging new perspective that necessitates a re-examination of the differentiation between Rodley's refectory and courtyard types.

\section{TRAPEZA AND SO-CALLED REFECTORY MONASTERIES}

Naming them "after their most conspicuous feature", Rodley (1985, 9, 151) describes her "refectory type" as a loose grouping with no formal arrangement of elements, with complexes that fall into this group comprising only a refectory, a church and one or two roughly, undecorated carved rooms (Figure 1).

In general, after the church, the refectory was the second most important architectural element within a Byzantine monastery and its location within the complex was related directly to the location of the former (Popović, 1998, esp. 283, 302; 2007, esp. 48) (15). According to Popović (1998, 303), who emphasizes the commemorative meaning of the communal meal for the first Christians, the "two buildings provided a joint setting for an 

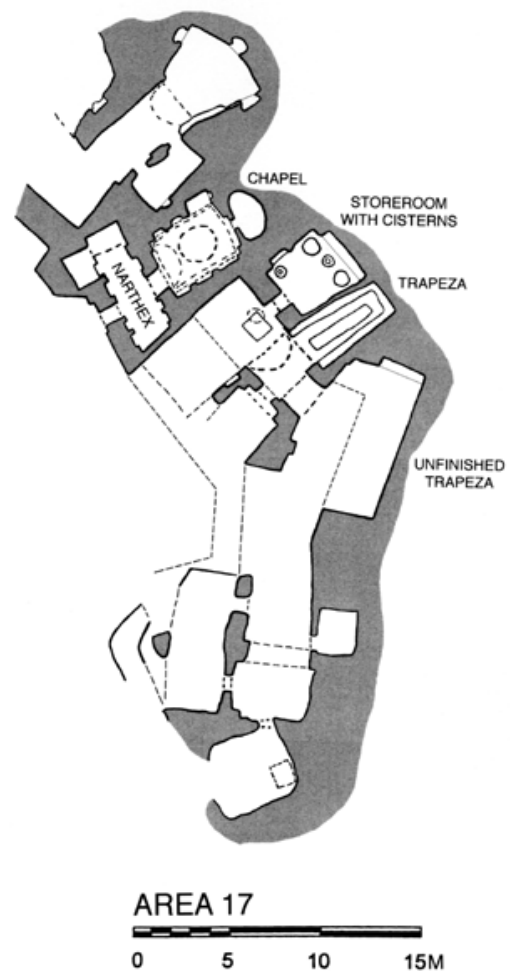

Figure 1. Refectory monastery (Area 17) at Çanlı Kilise, reconstructed plan (Ousterhout 2005a, Fig. 176).

Figure 2. Rock-cut refectory (trapeza) in Çarıklı Kilise, Göreme (photograph by Murat E. Gülyaz).

16. See also Kazhdan and Johnson (1991, 2109).

17. See also Kazhdan and Johnson (1991, 2109) and Footnote 41 below.

18. Rodley $(1985,118)$ mentions its façade in the appendix of her "courtyard monasteries" without recognizing that it contains a rockcut refectory. Jerphanion (1925-42, I: 254) also mentions a refectory by the complex Kilıçlar, but the photograph (Jerphanion, 1925-42, pl. 25.3) of it that he published is not from the refectory opposite. I thank Robert Ousterhout for his remark on this.

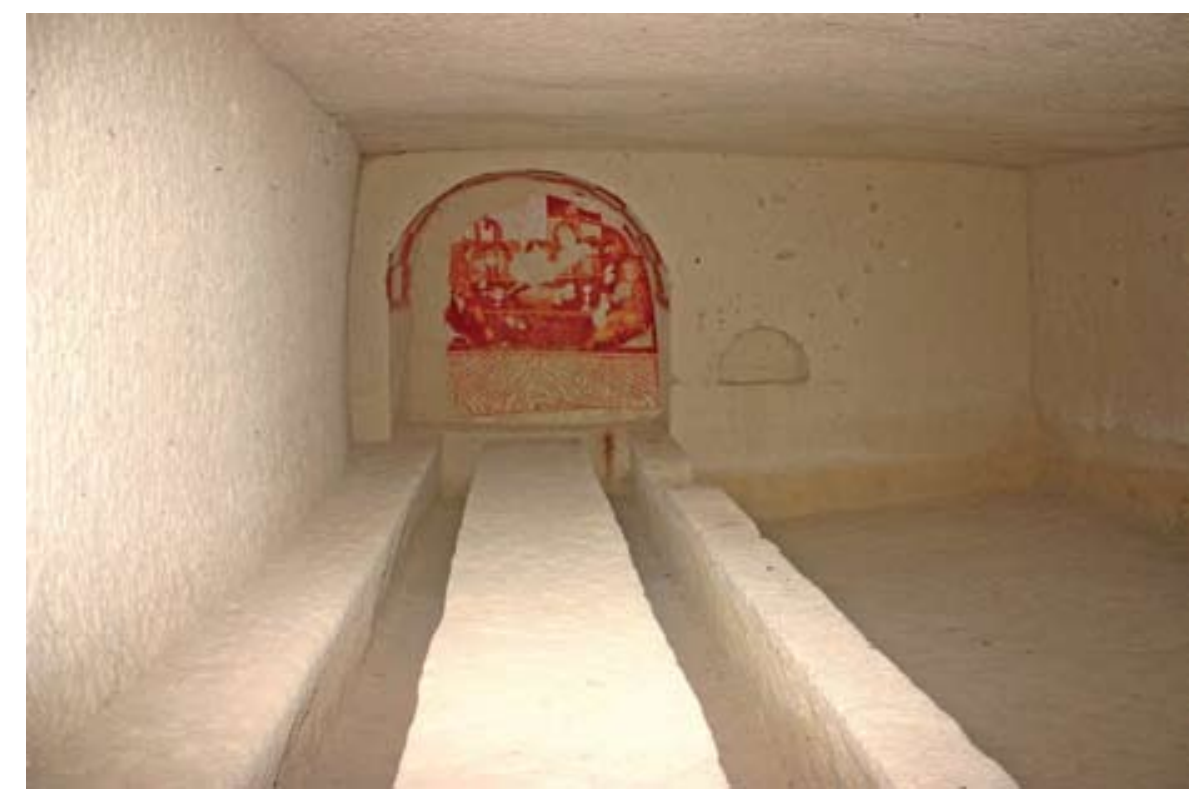

integral monastic ritual that began in the church and ended in the koinobion trapeza" (16). Nevertheless, Popović $(2007,48)$ also writes that "[o]bviously, its [the refectory's] function was dual, secular and religious". Indeed, besides its religious purpose, the refectory was also a secular space where daily meals would be served, and therefore had to be reasonably linked with the kitchen (Popović, 2007, esp. 50, 60-1).

The common basilical, or single-aisled Byzantine refectory plan was a rectangular space that in some examples was divided into bays. Cruciform and T-shaped plans were seldom (Popović, 1998, 297) (17). As for the interior articulation, the apse was commonly used "[i]n the central regions of Asia Minor and in the Balkans, especially during the middle Byzantine period" (Popović, 1998, 297). The room was often occupied by permanent furniture such as masonry tables and a stone lectern for religious readings (Popović, 1998, 285; 2007, 48). Tables were organized in two ways: either as rows of semi-circular tables placed along the walls; or as a single long table in the center, sitting in line with the main axis (Kazhdan and Johnson, 1991, 2109; Popović, 1998, 299).

As Rodley (1985) asserts, there are several carved structures containing a special room with a long rock-cut table (trapeza) and benches that at first sight would appear to have been parts of Cappadocian monastic establishments (Figure 1, 2). She exemplifies eleven such cases, which have been found clustered in the Göreme Valley within the Open Air Museum, and another two examples, Yusuf Koç Kilisesi and Archangel Monastery; the former located near the village of Avcilar and the latter near the village of Cemil (Rodley, 1985, 151-83). Nevertheless, recent studies (Pierre Lucas, 2003; Ousterhout, 2010) show that refectories are considerably more in number than initially noted by Rodley (1985). Pierre Lucas (2003) mentions more than twenty-five refectories carved just outside the Göreme Open Air Museum. Unlike the groupings mentioned by Rodley, many of them are isolated without forming a complex and without any church or chapel in the vicinity (Ousterhout, 2010). There are yet other refectories which seem to have been part of an establishment, such as the refectory opposite the courtyard complex Kılıçlar near Göreme (18); the refectory by Geyikli Kilise 
19. For Geyikli Kilise see Jerphanion (192542, II: 369-74); Kalas (2000, 42; 2009a, 157); and Ousterhout (2010, 91); For further bibliography on it see Ousterhout (2010, Footnote 14).

20. Ousterhout (2005a, 108-11) identifies Area 17 at Çanlı Kilise as the only monastic establishment in the large settlement where he noted more than twenty complexes.

21. See also Kalas (2009a, 157-61); Kalas (2009a, 157) emphasizes the lack of rock-cut refectories "in the entire Peristrema Valley and at the site of Açık Saray". See also Kalas (2009c, 194)

22. For Byzantine and Roman tombs in and around Göreme see Thierry (1984; 1987);

For burial practices in Cappadocia see Grishin (1989, esp. 46), Hill (1994, 138) and Teteriatnikov (1996, 165-182); Interestingly, yet, in the vicinity of ensemble of courtyard complexes such as Çanlı Kilise, SelimeYapakhisar and Açıksaray, despite the existence of open-air cemeteries, burials in church narthexes and naos, and separate funerary chapels, not a single refectory has been found (except for Area 17 in Çanlı Kilise); For burials at Çanlı Kilise see Ousterhout (2005a, 89-91, 165-6); at SelimeYaprakhisar see Kalas (2009b); at Açıksaray see Öztürk (2010, 168-9).

23. For more information on the Roman funeral banquet and its continuity in Christianity see Jensen (2008, esp. 107).

24. The Archangel Monastery near Cemil seems to be only example found in Cappadocia to date with two parallel rockcut tables. See Rodley (1985, 157-60).

25. See also Popović $(1998,290)$.

26. Popović (2007, 48); See also Kazhdan and Johnson (1991, 2109) and Popović (1998, esp. 299).

27. See Popović (1998); Popović $(1998,291)$ mentions Armenian refectories where "[e] ach bay had a four-pitched roof with apex openings in its center". Interestingly, this brings immediately to mind Cappadocian square kitchens with high chimney-vaults rather than Cappadocian flat-ceilinged refectories.

28. Popović $(1998,291)$ likens Cappadocian refectories to other carved refectories from the mountainous regions of Georgia.

29. For the strategic position of Çanlı Kilise, see Ousterhout (2005a, esp. 7-9, 182-4); of Selime-Yaprakhisar, see Kalas (2000, esp. 156-9; 2005; 2007a, 281, 292; 2007b, 406-7, 412-3); and of Açıssaray, see Rodley (1985, esp. 150), Grishin (2002) and Öztürk (2010, 157-97).

30. Most recently the author, in Öztürk (2010), examined 43 complexes, and offers an extensive and comparative architectural study of courtyard complexes, with the main focus being on the Açıksaray group. Since not all of the 43 complexes were accessible, only the 31 complexes recorded by the author or by previous scholars could be examined in terms of their internal organization.

Accordingly, the recorded courtyard complexes under consideration are: nine complexes (Areas 1, 4, 5, 6, 7, 12, 13, 15, 16) in the Soğanlı Valley (19) and the refectory in Area 17 at Çanlı Kilise (20). Nilüfer Peker and Tolga Uyar $(2010,286,294)$ recently reveal another rockcut refectory found around Güzelöz. This makes, all together, about forty rock-cut refectories in Cappadocia, and it is highly likely that there are still more awaiting discovery. Nevertheless, Rodley's $(1985,249)$ initial remark, that refectory monasteries are concentrated in the Göreme Valley, is still valid (21).

The unusually high number of isolated refectories carved side-by-side around Göreme has led scholars to reconsider their function. As already pointed by Rodley $(1985,250)$, Pierre Lucas $(2003,41)$ too talks about refectories in the context of venerated pilgrimage sites. Robert Ousterhout $(2010,97)$, on the other hand, pointing to the emphasis on burials in the vicinity of refectories, questions their monastic identity, and asks: "[m]ight the scattered trapezai be understood as a late, distant relative of the Early Christian triclia, used for the refrigeria meals at the Roman catacomb?" (22) Indeed, in more general terms, Popović (1998, 300-1), recalling the location of early refectories next to the burial caves in the Christian East; and the from the middle- and late-Byzantine period, in which the refectories generally open towards the church narthex with a funerary function, also proposes that "one must look to another ritual performed in the early days of Christianity, the funeral banquet, as a source of the form of the refectory building and its ritual" (23).

As for Cappadocian refectories belonging to a grouping, the number and size of related rooms suggest a small number of monks, perhaps fewer than ten in most cases; however, this contradicts the higher number of monks that may be deduced from the size of the refectory, in which thirty to forty people would be able to sit around the single long table that was usually carved on one side of the room (Rodley, 1985, 249) (24).

The presence of an apsidal niche, which in all probability would have been the area reserved for the abbot at the head of the table, implies a strict hierarchy in the seating arrangements (Kostof, 1972, 51; Rodley, 1985, 247; Popović, 1998, 302; Kalas, 2000, 40; 2009a, 157). In Çarıklı Kilise (unit 1) in Göreme the niche at the head of the table is decorated with a representation of the last supper, which makes its monastic identity almost certain (Figure 2) (Ousterhout, 2010, 97) (25). Nevertheless, although the interior walls of refectory buildings elsewhere were usually decorated with "symbolic images" (26) the example in Çarıklı Kilise is rather an exception within Cappadocian refectories. Similarly interesting, although built refectories found elsewhere in Byzantine monasteries usually have high ceilings that are either vaulted or domed (27), Cappadocian refectories have low and flat ceilings, and are rather crudely carved (28). This is remarkable, since Cappadocian carvers tended to imitate built forms, as can be seen in the hundreds of rock-cut churches and courtyard complexes in the region. Even the elaborately carved refectory in the Geyikli Kilise, which is decorated with carved niches, featured only a simple flat ceiling.

\section{COURTYARD COMPLEXES}

As for courtyard complexes, over forty examples have been discovered within the areas occupied by the modern cities of Aksaray, Nevşehir, Kayseri and Niğde. A concentration of such complexes can be observed at strategic points close to fortresses or military roads at three sites: Çanlı Kilise, Selime-Yaprakhisar and Açıksaray (29); while others are spread 
at Çanlı Kilise; four complexes (Areas 2, 5, 7, 8 ) at Selime-Yaprakhisar; eight complexes (Areas 1, 2, 3.1, 4, 5, 6, 7, 8 (Nos. 7, 4, 2a, 2, 1, 5, 6, 3 by Rodley, 1985) at Açıksaray; and the ten isolated complexes listed above. See also Öztürk (2010, Table 2).

The corpus of Rodley $(1985,11-120)$ covering 11 "courtyard monasteries", excludes the ensemble of courtyard complexes. She (1985, 121-50) investigates the seven complexes at Açıksaray as a separate group. The corpus of Mathews and Daskalakis-Mathews (1997, 298) covering 16 complexes includes only the Açısaray group from the category of ensemble of courtyard complexes. For an extensive survey of the Çanlı Kilise group, see Ousterhout (2005a). For an extensive survey of the Selime-Yaprakhisar group, see Kalas (2000) and other related works in the Bibliography.

Kalas (2009b, 81) differentiates between the "courtyard units" that are "located randomly and in isolation" and those which are "concentrated in one locale". Strikingly, however, she includes Göreme, in which there is a concentration of so-called refectory monasteries, also in the latter category.

Due to the complex character of Cappadocia it is highly probable that there are other courtyard complexes, maybe less well organized, still awaiting for discovery.

Figure 3. Hallaç, courtyard complex, plan (Ousterhout 2005a, Fig. 238 (redrawn, based on Rodley, 1985, Fig. 2)).

Figure 4. Açıksaray, Area 2 (No. 4 by Rodley, 1985), reconstructed elevation of the main façade (reconstruction and drawing by author).
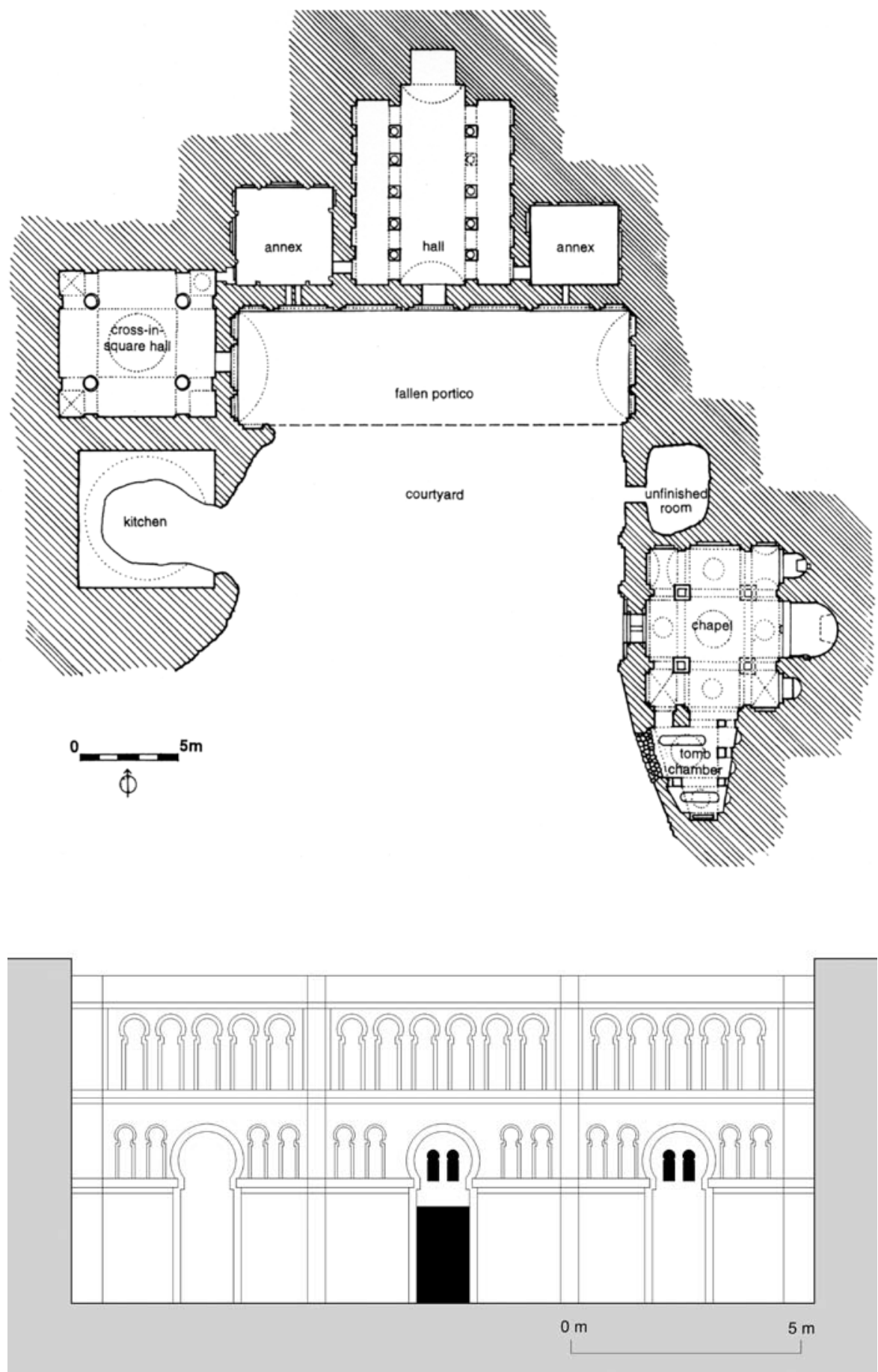

across the volcanic valleys. Accordingly, courtyard complexes can be divided into two sub-categories: ensemble of courtyard complexes, covering these three sites of concentration; and isolated courtyard complexes, covering ten other isolated examples - Direkli Kilise, Karanlık Kale, Eski Gümüş, Soğanlı Han, Erdemli, Şahinefendi, Aynalı Kilise, Hallaç, Kılıçlar and Bezir Hane (30).

Courtyard complexes were often organized around a three-sided courtyard, as in the case of the Hallaç complex near Ortahisar, which is often used to exemplify this type of complex (Figure 3) (Mathews and 
31. Hallaç was the first of Rodley's (1985) "courtyard monasteries" to be referenced subsequently by scholars, including Mathews and Daskalakis-Mathews (1997); Ousterhout (1997b; 2005a) and Kalas (2000; 2009d).

32. Mathews and Daskalakis-Mathews (1997) were first to offer the inverted T-Plan as an argument for the secular function of the courtyard complexes, while pointing to its domestic use by the Muslim neighbors. For a critical approach to the origin of the inverted T-plan and cultural interchanges, see Ousterhout (2005b, esp. 216-7).

33. See Footnote 30 above

34. There were all together 28 longitudinal halls, to borrow the terms "longitudinal halls" and "centrally planned halls" from Ousterhout (2005a). Ousterhout (2005a, 14551) came up with this differentiation while surveying Canlı Kilise. For a detailed and comparative study of the halls of courtyard complexes, see Öztürk (2010, 212-220 and Table 2).

35. Reiterated by Kostof (1989, xvii). See also Öztürk (2010) 57.

36. Ousterhout (2005b, 215) writes, "I am unsure how to define the function of the formal spaces: were they common living spaces, reception rooms, audience halls, or triclinia?"

37. See footnote 34 above.

38. For the plan of Selime Kalesi see Rodley (1985, fig. 13) and Kalas (2007a, fig. 9); for the plan of Karanlık Kale see Rodley (1985, fig. 16).

39. Kalas (2007a, 285) alternatively suggests that this cruciform room might have been the "private bedchamber of the head of the household". See also Kalas (2007b, 411)
Daskalakis-Mathews, 1997, 299; Kalas, 2009b, 81) (31). Accordingly, the so-called "inverted T-plan", consisting of a vestibule lying parallel to the cliff and a perpendicular longitudinal hall, has attracted the most attention from scholars citing the secular/ domestic function of courtyard complexes (32). More interestingly, these apparent reception spaces, which give no indication of having a religious use, were usually carved behind high and elaborately decorated façades that could have been seen from great distances (Figure 4). This clear intention to express status is in direct contradiction to the monastic ideal of a modest life (Ousterhout, 2005b, 215; Kalas, 2009a, 165). Moreover, results of a recent comparative study by the author (Öztürk, 2010) have supported existing evidence that not all of the complexes of the courtyard type contain a church, and none of them has a rock-cut refectory. Instead, they occasionally include a spacious kitchen and a large stable, as well as rooms that were apparently multifunctional.

\section{a.Triclinium}

Of the 31 courtyard complexes in the sample (33), 25 had at least one longitudinal hall (34), which was generally located along the central axis of the courtyard and usually constituted the main hall of the complex (Figure 3). More than two-thirds of these halls were entered through a horizontal vestibule that lies perpendicular to the hall, forming an inverted T-plan. More interestingly, half of the examples of longitudinal halls had either a niche or a room carved into the farthermost end facing the central entrance. This indication of a hierarchy among the people occupying the same room led some scholars to identify these halls as refectories, while leading other scholars to suggest a secular receptional use. In this respect, Rodley (1985, 247), insisting on her monastic identification of courtyard complexes, suggests that these spacious halls probably constituted refectories that may once have been furnished with wooden rather than rock-cut furniture (35).

Offering a contrasting view, Ousterhout (2005a, 147) supports the secular identity of the courtyard complexes, ascribing "central importance" to the longitudinal halls in daily activities; and suggesting that their function may have been as a reception area in which "the head of the household" rather than the abbot would have been seated at the emphasized end (36). Ousterhout $(2005 a, 150)$ claims that there is insufficient evidence to support the existence of "formal dining in the Middle Byzantine period", and likens (2005a, 147) the Cappadocian longitudinal halls to the halls that started to appear in late antiquity houses, when public architecture had declined and public affairs began to be conducted within the house. Also speaking in support of the idea of domestic use, Thomas Mathews and Annie-Christine Daskalakis-Mathews $(1997,300)$ claim that even though the Byzantines may have referred to the main hall in a courtyard complex as a triclinium, or dining room, it may well have had a similar function to that of the Islamic $q a^{\prime} a$, that is, serving multiple purposes, such as for dining, leisure and business.

More interestingly, besides longitudinal halls, one-third of the 31 courtyard complexes contain an additional centrally planned hall (Figure 3) (37), crossin-square or cruciform in plan and with a dome, with entry being through the vestibule in half of the cases. The similarity in their form, size and location at the core of the complex is striking. The cruciform halls in Selime Kalesi and Karanlık Kale were directly connected to the main longitudinal hall and communicated only through them (38). Veronica Kalas (2000, 148) identifies the former as the probable triclinium (39); while Ousterhout $(2005 a, 151)$ could not assign a specific function to the centrally planned 
40. The only exception in the sample is the centrally planned hall of Area 4 (No. 2 by Rodley 1985, fig. 20) in Açıksaray, which was not secondary but the prominent main hall per se. See Öztürk $(2010,170)$ and Rodley $(1985,125) ;$ Mathews and DaskalakisMathews $(1997,302)$ suggest a function as women's quarter for the centrally planned hall in Hallaç (Figure 3). In this respect, see also Ousterhout $(2005 b, 215)$.

41. Popović $(1998,302)$ points to the basilical halls from late antiquity as the origin of the architectural form of the refectory. Nevertheless, mentioning the scholarly works that point to the late-antiquity and early-Byzantine triclinia as the origin of refectory architecture, Popović $(1998,300)$ emphasizes the introverted nature of the latter in contrast to the intended visual connection between interior and exterior by the triclinium.

42. Rodley $(1985,247)$ differentiates between "wide domes, conical or pyramidical vaults". Mathews and Daskalakis-Mathews (1997, 298) mention kitchens "identifiable by funnel chimneys". Ousterhout (2005a, 152) identifies kitchens in Çanlı Kilise as "usually a square room covered by a conical chimney-vault". Kalas $(2007 a, 277)$ describes that the "kitchen has a conical ceiling with a ventilation shaft at its summit". Kalas (2009d, 112) differentiates between the larger kitchens with "a more angular, pyramidal shape to the sloping ceiling", and smaller kitchens with "simpler, conical ones". See also Kostof (1989, xvii); Kalas (2000, 87-9; 2004, 108; 2007b, 399-400; 2009a, 165-6; 2009d, esp. 109); and Öztürk (2010, 228-31).

43. See Footnote 51 below.

44. See Sigalos $(2004,56)$

45. Sigalos (2004, 58-59) yet warns that although archaeological data is still lacking "we cannot dismiss the possibility that particular areas within rooms, or even whole rooms, were reserved for cooking".

46. Doğan $(2008,1)$ emphasizes that although houses found in Alanya have characteristics of the early Byzantine period, they were in use from the fifth to the twelfth century. halls, choosing to describe them as "secondary formal spaces" (40). In the peristyle houses of late antiquity, Simon Ellis $(2004,39)$ claims that the hall "with three or more apses, lying immediately to the right of the triclinium", would have been a grand dining hall for the hosting of formal banquets by the local aristocracy. In this respect, the centrally planned hall found in the courtyard complexes would likely be used as a more formal dining room; but unlike examples from late antiquity, they were not usually isolated, but were rather at the core of the complexes.

As exemplified above, regardless of the proposed identity of the courtyard complexes, scholars generally agree that the spacious halls served for the taking of meals, although those speaking for a secular identity believe that this was not their only function. This is not surprising, since scholars such as Nicolas Oikonomidès $(1990,212)$ suggest there were probably similarities between the rules for imperial banquets, banquets of high society and the rules of monastic refectories; while, Popović $(1998,298)$ asserts that "[c]ontemporary palace architecture no doubt had an impact on refectory architecture" (41).

\section{b. Kitchens}

At this point, Rodley's suggested caution at the very outset in her definition of so-called "courtyard monasteries" deserves particular attention:

“The terms 'vestibule' and 'hall' are used here for convenience and do not carry precise implications of function. It is not usually possible to know exactly what functions were served by the individual elements of a complex, except in the obvious cases of churches and kitchens." (Rodley, 1985, 11)

Indeed, especially remarkable in courtyard complexes is the high frequency of a square room with a huge chimney-vault, either conical, pyramidal or domical, implying a kitchen (Figure 5-7). Rodley $(1985,19)$, while recording the complex in Hallaç, identified specifically room 6, which contained "a fairly steep dome rising above a deep overhang", as the kitchen (Figure 3) (42). Pointing to the smoke hole as clear evidence, she mentions that "rooms of this type" had also been discovered in other complexes (43).

The Cappadocian kitchens under consideration are rather extraordinary, since cooking and household production, for instance, in the Middle Byzantine houses in Greece would normally be done in the courtyard, as was the case in ancient times (44). While the majority of these houses did not feature hearths to indicate clearly the location of kitchens, a brazier set in the courtyard might have served for cooking (45). In contrast, Clive Foss $(1976,70)$ reports that the Middle Byzantine houses in Sardis consisting of one or more rooms usually included a semi-circular brick hearth; and likewise, one room in the larger houses in Byzantine Pergamon often featured a hearth built into one of its walls. Other than the presence of a hearth, these rooms bear no architectural differences to the rest of the house, and in smaller houses the same room was used for living, cooking and storage (Rheidt, 1990, 199). In Alanya too, archaeological evidence has been insufficient in allowing a differentiation of specific functions related to specific spaces within the Byzantine house, and as such no room could be identified with certainty as a kitchen by the survey team (46). On the other hand, Semavi Eyice $(1996,209)$ mentions that "a small room with a rectangular opening in the middle of its vault" found in a Byzantine brick house in Side was in all likelihood the kitchen.

Greek monasteries, it would seem, not only had spaces reserved for dining in the form of refectories, but also spaces set aside for cooking. 
47. Rodley $(1985,247)$ refers to Orlandos (1927, 61-8).

48. Kalas (2009d, 115), also referring to Orlandos (1927, 37-45), emphasizes this as a "more logical design solution in a masonrybuilt structure".

49. Yet, Kalas (2009d, 110-1) also voices the difficulty of stratigraphic investigation in Cappadocia where the architecture is still standing, but where small finds to confirm the function are usually absent; For difficulties related to the archaeology of Byzantine housing, see Rheidt (1990; 1996), Eyice (1996), Tanyeli (1996), Kalas (2007b).

50. See Footnote 72 below.

Figure 5. Selime Kalesi, kitchen (photograph by author).

Figure 6. Açıksaray, Area 5 (No. 1 by Rodley, 1985), kitchen (photographs by author).

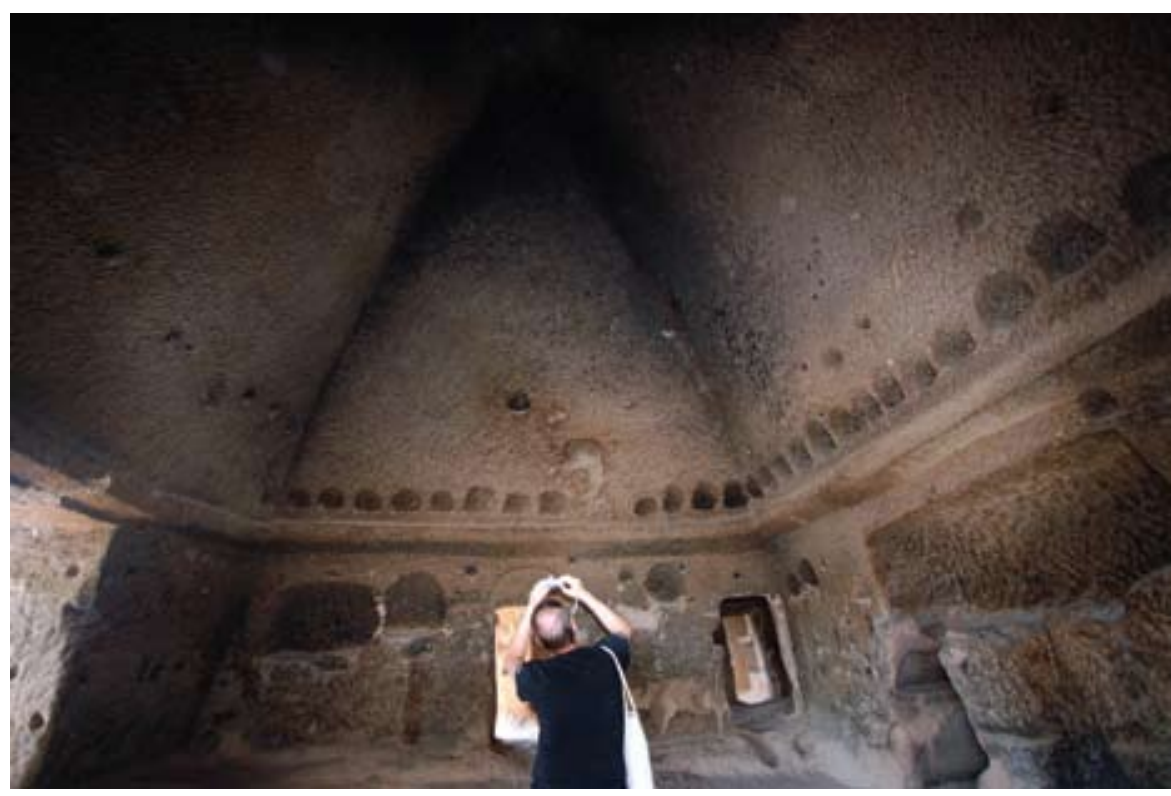

Accordingly, Rodley claims that the kitchens of Cappadocian courtyard complexes "are of a type traditional in the Greek monasteries and probably generally" (47). Kalas, on the other hand, points out that although also square in form, the built kitchens of the late- and post-Byzantine monasteries of Greece have domical vault roofs rather than conical or pyramidal ceilings, as seen in Cappadocia (48).

Kalas (2009d, 109-10), indicating the difficulties involved in the study of medieval archaeology, highlights the importance of the kitchens of Cappadocia, which have been preserved not only in plan, but also in elevation (49). Indeed, in contrast to the scarcity of surviving built kitchens, almost two-thirds of the Cappadocian courtyard complexes had spaces especially designed for cooking for large numbers of people (50). Accordingly, 18 kitchens found in 31 recorded complexes have "standard"
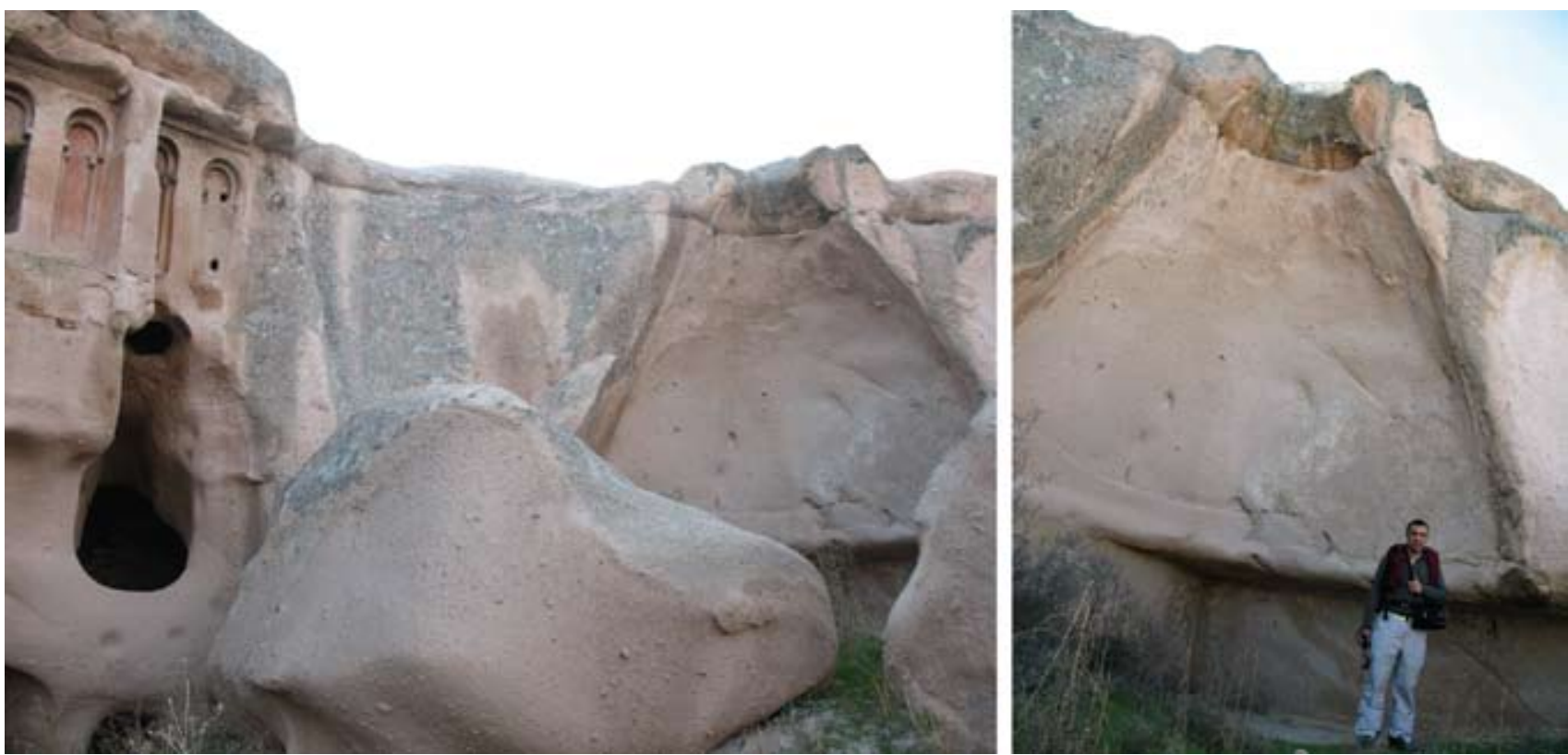
51. See Öztürk (2010, 228-31 and Table 2); Kitchens in Açıksaray Area 5 (see Öztürk, 2010, fig. 6.33, 6.64 and 6.65), Soğanlı Han (see Öztürk, 2010, fig. 5.2.3 and 5.2.17) and Kılıçlar (see Öztürk, 2010, fig. 5.2.7 and 5.2.32) have been newly discovered and for the first time recorded by the author.

Rodley (1985) mentions a total of nine kitchens found at Hallaç, Şahinefendi, Karanlık Kale, Eski Gümüs, Selime Kalesi, Açıksaray Areas 3.1, 4, 7, 8 (Nos. 2a, 2, 6, 3 by Rodley, 1985).

On the other hand, Kalas (2009d) lists a total of 23 kitchens, including those whose identification is uncertain or which do not have "typical" characteristics. More interestingly, at Çanlı Kilise her list even includes kitchens which do not belong to a courtyard complex, covering nine kitchens (in Areas 1, 3, 6, 13, 14, 17, 19, 23 and the East Settlement) at Canlı Kilise; six kitchens (in Areas 2, 5, 7, 8, 11, 15) at Selime-Yaprakhisar; four kitchens (in Areas 3.1, 4, 7, 8 (Nos. 2a, 2, 6, 3, by Rodley, 1985)) at Açıksaray; and another four recorded kitchens by Rodley at Hallaç, Şahinefendi, Karanlık Kale, Eski Gümüş.

52. Kalas (2009d, 114) refers to Ousterhout (2005a, 152). In Çanlı Kilise, Ousterhout notes the appearance of "the standard form" in Areas 5, 13, 23 and in the East Settlement. He probably mistakenly writes Area 5 instead of Area 6. For the plans see Ousterhout (2005a, fig. 122, 155 and 195).

53. Ousterhout (2005a, 121) himself points to the "unusual organization" of the East Settlement, and suggests that it was in all probability a monastery, contemporary with the main settlement at Çanlı Kilise. In addition, each of the kitchens in Areas 6 and 13 was carved behind the vestibule next to the hall, which was not a usual location for the kitchen in a courtyard complex. More interestingly, Area 23 shows a haphazard layout, and is not at all a "well organized" unit.

54. Even more interestingly, following her unfounded claim, Kalas $(2000,88)$ suggests that "the number of people found worshipping in the church at any given moment could also be found cooking in the kitchen". This would mean that men also took part in the traditionally femaledominated duty of cooking, which would be a highly unlikely scenario.

55. See Öztürk (2009).

56. See Öztürk (2010, esp. 198-241 and Table 2).

57. See Öztürk (2010, 229).

58. See also Kalas (2009d, 117). features, and their identification is without doubt. These are: three kitchens (in Areas 1, 6, 13) at Çanlı Kilise; four kitchens (in Areas 2, 5, 7, 8) at Selime-Yaprakhisar; five kitchens (in Areas 3.1, 4, 5, 7, 8 (Nos. 2a, 2, 1, 6, 3 by Rodley, 1985)) at Açıksaray; and six kitchens in Hallaç, Şahinefendi, Karanlık Kale, Eski Gümüş, Soğanlı Han, Kılıçlar from the category of isolated courtyard complexes (51).

Kalas (2009d, 113), who wrote a recent article on Cappadocian kitchens, asserts that " $[t]$ he kitchens in Areas 6, 13, 23, and the East Settlement [at Çanlı Kilise] are considered to present the typical arrangement, whereas remaining examples vary in form". She suggests that "typically arranged kitchens tend to belong to the more 'well organized' units" (52). Nevertheless, such simplifications, which are based on a limited number of examples, can be confusing (53).

Kalas (2009d; 2000, 88) further discusses the kitchen in relation to the church of the complex, comparing both components in regard to their plan, dimension and location. Accordingly, Kalas claimed that in general the kitchen and the church were often of similar dimension in the courtyard complexes, going even further to suggest:

\section{"Because both the Middle Byzantine cross-in-square church and the kitchen are essentially square in plan, perhaps the carver set out to establish a square room of a certain dimension and repeated it once for the church and once for the kitchen, though the two rooms would be finished in a very different fashion in elevation." (Kalas, 2009d, 115) (54)}

At this point it should be recalled that carving differs from conventional building processes, in that it allows more individuality. Unlike conventional materials, such as reinforced concrete or brick, the material of carving requires no form, nor does it depend on a standardized module. In contrast, the dimension of the carved spaces strongly depends on the characteristic and limitations of the particular rock layers encountered while carving (55). It is also worth noting that the church and kitchen were not unique in terms of size, as several other spaces also shared similar dimensions.

Concerning the location of the kitchen, Kalas $(2000,87 ; 2009 d, 111)$ claims that when possible it was located on the opposite side of the courtyard to the church; yet a recent comparative study of courtyard complexes conducted by the author showed that one-third of complexes with kitchens (6 of 18) had no attached churches at all. Of the 12 complexes that included both a church and a kitchen, 10 indeed had a cross-in-square church; but of these 10 complexes, only in four was the kitchen obviously located across from the church (56). On the other hand, 13 of 18 kitchens opened directly onto a courtyard or a front door space. While only one of them had an additional entrance from the vestibule, two of them had an indirect additional entrance from the vestibule via another in-between room. Only in one case was the kitchen located upstairs; and the rest (4 of 18 kitchens) were entered from the vestibule. Additionally, one had a second entrance from the hall, which constitutes the only exception in our corpus for a direct connection between the kitchen and the hall (57). To conclude, although the kitchen was not far from the core of the complex, it had a rather "secondary position" (Ousterhout, 2005a, 152) (58).

Kitchens are generally the most heavily eroded spaces within a complex due to their location facing directly onto the courtyard, and owing to their spacious ceiling and open smoke hole. Nevertheless, their square plan and 
Figure 7. Açıksaray, Area 3.1 (No. 2a by Rodley, 1985), kitchen (photograph by author).
Figure 8. The crude kitchen at Archangel Monastery, Cemil (photograph by Tolga B. Uyar).

59. See also Figure 3, 4 for Selime Kalesi and fig. 10 for Yaprakhisar 11 in Kalas (2009d).

60. See Rodley (1985, 82); Kostof (1989, xvii); Kalas (2000, 87; 2007b, 400, 407; 2009d, 112, 116-7); Öztürk (2010, 230).

61. See Kalas (2000, 139; 2007a, 287-8; 2007b, 407; 2009d, 112, 116-7) and Öztürk (2010, 230): Kalas (2009d, 117) suggests that a portable brazier might have been used as a supplementary cooking device in courtyard complexes, although none has been found. The tandir probably was not used in the Byzantine period and is rather a later development. I thank Robert Ousterhout for his remarks on this.

In fact, two different forms of tandir are still in use in the modern-day villages of Cappadocia, where cooking takes place in the courtyard or in the roofed recess, the
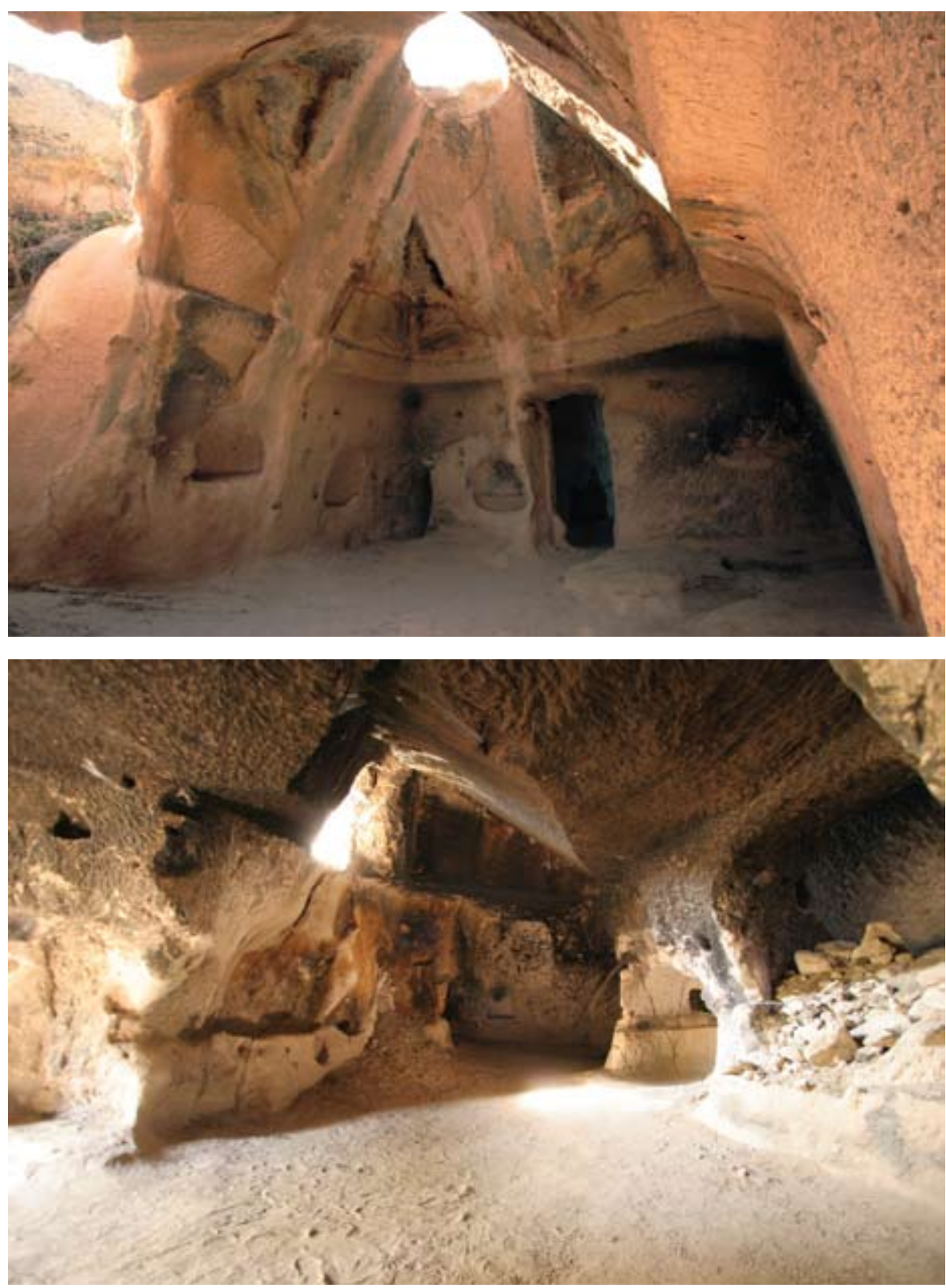

form is still readable, and accordingly, Kalas (2009d, 112) has been able to differentiate between larger kitchens with pyramidal ceilings (Figure 5, 7) and smaller kitchens with conical ones (Figure 6). The larger kitchens measure about 7-8m x 7-8m, as in Areas 2 (Selime Kalesi) and 11 at SelimeYaprakhisar; while the smaller kitchens measure $4-5 \mathrm{~m} \times 4-5 \mathrm{~m}$, and as emphasized by Kalas, are more common (Kalas, 2009d, 112-4) (59).

Despite suffering severe damage, it can be still observed that several kitchens had at least one elongated and a few smaller niches which acted as shelves; and a semi-circular niche that would have served as a hearth, all of which were carved into the surrounding walls (60); while some also contained a so-called tandır, a circular hearth dug into the ground for heating and cooking (61). Another typical feature of these kitchens is a number of adjacent smaller rooms that may have provided extra space for storage and food preparation (62). Interestingly, pit-looms have been found 
so-called çardak. Another room in the interior of modern-day village houses can also be described as a kitchen, traditionally referred to as tafana, and is only used, if ever, during the winter. It rarely possesses a hearth, and as such is more commonly used as a storage area for food and cooking utensils (Emge, 1990, 56). For contemporary uses of the tandır see also Stea and Turan $(1993,191)$.

62. See Rodley $(1985,98)$; Kalas (2000, 139; 2007b, 400; 2009d, 112, 116); and Öztürk (2010, 230, 233-4).

63. See Kalas (2005, 258-9; 2007a, 288; 2009d, 114) and Öztürk (2010, 230).

64. For Karanlık Kale see Rodley $(1985,98)$. For Açıksaray, see Rodley $(1985,130)$ and Öztürk (2010, 166). See also Kalas (2009d, 116).

65. Popovic $(2007,61)$ asserts that secular spaces such as kitchens in a monastic complex often represent "the epitome of the actual architectural trends".

66. For the conceptual differences between carved and built architecture, see Kostof (1989, 18); Ousterhout (2005b, esp. 219-23); and Kalas (2007a, 292; 2009d, 115-6); For the traditional methods and techniques used prior to mechanization, and still practiced by some modern Cappadocian carvers, see Öztürk (2009).

67. See Rodley (1985, fig. 20) and Öztürk (2010, fig. 6.33).

68. Reiterated by Kostof (1989, xvii); See also Öztürk (2010, 139).

69. For instance, the room marked as "kitchen and storage" in the Open Air Museum in one of the refectory monasteries in Göreme has a low flat ceiling without a chimney, merely containing a tandır; See also Footnote 61 above.

70. Kalas (2009d, 117) suggests that a large wooden table might have been set up in the middle of the room to allow work to be carried out; See also Öztürk (2010, 230).

71. Kalas (2007a, 288) uses the existence of pit-looms to emphasize the domestic function of the complexes.

72. See also Kostof (1989, xviii) and Kalas (2000, 89; 2007b, 407-8); Kalas (2009d, 117) writes: "the separate location of the kitchen from the rest of the house, indicates that cooking could have been conducted at all hours of the day and in large quantities".

73. See also Kalas (2009d, 117) and Footnote 29 above.

74. See Öztürk (2010, Table 2)

75. Rodley (1985) mentions supposedly rockcut refectories in Karanlık Kilise and Eski Gümüş, which she listed under her courtyard types. In Eski Gümüș (see Rodley, 1985, fig. 17), Rodley $(1985,109)$ mistakenly suggests that irregular holes and forms carved in the floor of the longitudinal main hall were probably the remains of a refectory, yet it is obvious that they were not, as they would appear rather to have been graves and / or secondary works. More interestingly, Rodley (1985, 48-56) categorizes Karanlık Kilise (see Rodley,1985, fig. 9), despite the existence in some of the kitchens (63), and some contained carved benches, such as in Karanlık Kale and in Area 3.1 (no. 2a by Rodley, 1985) in Açlksaray (64), which might have facilitated the preparation of meals and other possible household productions.

Whether these kitchens were an imitation of a built form that is no longer in existence, or were peculiar to Cappadocia, or more generally to carved architecture, is questionable (Kalas, 2009d, 115) (65). Rather, the rock-carving architects of the region seem to have used their creativity in shaping a unique form while utilizing the opportunities offered by the topography (66). For instance, the kitchen (Room 5) in Area 3.1 in Açıksaray was carved deep into the rock, since only there it was high enough to form the pyramidal chimney-vault typical of these kitchens (Figure 7) (67); and for this reason it had to be connected to the courtyard and the rest of the complex via a long atypical tunnel (Öztürk, 2010, 166). Another example of topographical adaptation can be seen in the kitchen at Eski Gümüş, which was carved into an upper room in order to facilitate the opening of a chimney (Rodley, 1985, 110) (68).

Still, the size and form of these unique kitchens found in courtyard complexes cannot be explained solely by the idiosyncratic topographical settings, since they also differ from the crude spaces identified as probable kitchens in the refectory monasteries (Figure 8) and in rock-cut settlements elsewhere in Cappadocia (69).

\section{CONCLUSIONS}

It is likely that the kitchens of the courtyard complexes in Cappadocia were communal rooms that served for the daily gathering of the female members of the family, where they would carry out also duties related to household manufacture (70). This might explain the unexpectedly large volume of the room, as well as carved benches and pit-looms found in some cases (71). However this alone still does not explain for whom they were cooking and where the meals were taken, but the unique form and dimensions would indicate that they were cooking for many people. Accordingly, Rodley $(1985,248)$ asserts that "[c]ertainly the existence of large kitchens in most of these [courtyard] monasteries implies a larger community than the available housing suggests. Some of this capacity may, however, have been provided to accommodate guests" (72). Indeed, in Açıksaray, Çanlı Kilise and Selime-Yaprakhisar, several complexes with kitchens were carved side by side. This may have been a reflection of their strategically important locations as from time to time they may have been called upon to provide food for vast military camps (Kalas, 2000, 89) (73). On the other hand, the fact that six of the ten isolated courtyard complexes have surviving kitchens indicates that the kitchen was one of the crucial components in an independent establishment of this kind (74).

Most interestingly, none of the examples belonging to the courtyard type that included large kitchens contained built-in furniture for dining; just as hardly any of the refectory type that did contain rock-cut furniture featured any kind of kitchen, which were frequently found in the courtyard type (75).

Oikonomidès $(1990,213)$ interprets the presence of built-in furniture as a sign of a lower status in the Middle Ages. As Rodley $(1985,247)$ has already proposed, though having monastic use in mind, a wooden table and benches might have indeed been used in the courtyard complexes 
of a large rock-cut trapeza and benches, as "courtyard monastery" rather than refectory monastery. This is confusing, since it features no characteristics of the courtyard type, aside from an elaborate painting program in its church. Moreover, it is located in the Göreme Valley in the vicinity of other refectory monasteries. Yet, Rodley $(1985,250)$ suggests a "dual role" for it.

In Karanlık Kilise (Rodley 1985, 48-56, fig. 9) there is a highly eroded small-sized room with rather an irregular vault and a chimney, which might be a kitchen. I thank Robert Ousterhout for bringing this to my attention. In the Yusuf Koç Kilisesi, which is one of the refectory monasteries of Rodley (1985, 151-7, fig. 28) there is a similar small space with a chimney. Unlike the one in Karanlık Kilise this one has also a hearth carved into the wall below the chimney that is still used by locals. There is a large kitchen with an irregular plan but containing a chimney and a hearth in the Archangel Monastery near Cemil (figure 8) (Rodley 1985, 157-60). I thank Tolga Uyar for bringing this to my attention. Interestingly, none of these probable kitchens were mentioned by Rodley (1985).

Ousterhout (2005a, 110) mentions a probable kitchen belonging to the only refectory monastery (Area 17) at Çanlı Kilise, however the author could not identify this room during her visit. According to Ousterhout, this almost completely buried room has a flat-ceiling and a chimney carved near a corner. Ousterhout (2005a, 121) mentions a probable kitchen with a conical chimney found in the East Settlement at Çanlı Kilise, which he suggests may be a monastery; nevertheless, he is uncertain of the function of this heavily damaged room, and so speculates whether this L-shaped room was both a kitchen and storage room, or even a refectory whose rock-cut table might have been buried. See also Ousterhout (1997c, 306).

Jolivet-Lévy and Desmesnil (2009, esp. $86,94-5)$ have reported recently a kitchen with a conical chimney belonging to an establishment that she identified as monastic in the village of Bahçeli. Interestingly, this establishment has neither a rock-cut refectory nor a hall.

76. Karpozilos, Kazhdan and Cutler (1991, 2003) point out that use of tables was more common in the Byzantine than Roman period, especially following the transition in the 10th century from "reclining around a table" to "sitting at a table" for dining. Nevertheless, Kazhdan $(1991,809)$ asserts that although beds and tables constituted "the main pieces in a Byz. Houshold" $11^{\text {th }}-15^{\text {th }}$ c. wills and inventories are "strangely silent about beds, tables and chairs." In this respect, see also Oikonomidès (1990, 207-8).

\section{See Footnote 11}

78. See Popović (1998).

79. See Popović $(1998,282)$ and Mathews and Daskalakis Mathews (1997, 298).

80. Though, Rodley $(1985,249)$ admits that "there must have been kitchens of some sort" even when they "did not employ the formal architecture of the courtyard monastery kitchens".
(76), which are more commonly identified as elite houses (77), however one must be still careful in transporting this symbolic meaning to the Cappadocian examples where the entire complex is carved from rock. Furthermore, masonry tables and benches as permanent built-in structures can be found even in built refectories (78). On the other hand, even if main halls of courtyard complexes had indeed once been refectories furnished with wooden tables and benches, their large size and prominent positions compared with the secondary position of the small churches would be still unusual, to say nothing of the complexes that featured large halls but no church at all.

On the other hand, as already indicated by Mathews and DaskalakisMathews, another possible explanation for the lack of permanent furniture may be that the inhabitants of courtyard complexes in this border region had borrowed the habit of sitting on the floor from their Muslim neighbors. They suggest that:

"There is some evidence that Byzantines not bound to a monastic regimen dined in the much more relaxed, Islamic 'picnic' style, seated cross-legged on the floor or on cushions. Tables were dispensed with; food was passed about on platters or in large bowls." (Mathews and Daskalakis Mathews, 1997, 300-1)

Indeed, secular patrons of courtyard complexes would have had more freedom in this respect than the members of a monastic community, where communal meals were strictly regularized (79).

As for the so-called refectory monasteries, all of which feature rockcut table and benches, at first sight they are indeed more likely to have been monastic establishments. Rodley asserts that refectory monasteries, especially those concentrated in the Göreme Valley, were probably related with sites of religious importance, and suggests that visiting pilgrims may have been accommodated in local camps. Accordingly, while "small permanent communities" might explain "[ $t]$ he absence of rooms clearly identifiable as kitchens", long rock-cut table and benches might indicate "extra sitting space" for such visitors (Rodley, 1985, 24950) (80). Furthermore, the scarcity of kitchens might be explained either in terms of the simple diet of the monks, which did not require any specific installation; or with a food supply from outside (Kalas, 2000, 89) (81).

On the other hand, Ousterhout (2010) emphasizes the "commemoration of the dead" as a probable raison d'être of numerous refectories in Cappadocia. Indeed, the use of isolated refectories as refrigeria, as he proposed, would also explain the lack of kitchens, since in this case food and beverages would be brought by people gathering to commemorate the dead on occasion in the respective refectories. The simple interior articulations of these flat-ceilinged refectories might also support their only occasional use for the conducting of private meetings.

In this respect, Ousterhout $(2010,94)$ warns that "[m]onasticism in Cappadocia requires a much more nuanced approach than has been applied heretofore" (82). Likewise, its understanding also requires a look at the larger picture to include also the possible relations between both types cited by Rodley: the courtyard type and the refectory type. The proximity and visual connections between the courtyard complex Soğanlı Han and the refectory complex Geyikli Kilise, as well as between the courtyard complex Kilıçlar and the opposite refectory complex is remarkable, and may point to the nature of patronage in the region (83). In some cases, both 
81. See also Rodley $(1985,249)$ and Kalas (2009d, 115).

82. Similarly, Kalas (2009c, esp. 192-4) also warns against "strict categories" in the context of Cappadocia.

83. See Ousterhout (2010, 91-3).

84. See Footnote 4.

85. See Footnote 32 types can be interpreted as physically and conceptually complementary to each other, while in other cases the one might be raison d'être of the other.

To conclude, all of these assumptions, while based on different evidence, should be accepted only with due consideration, since while the volcanic landscape of Cappadocia has preserved numerous architectural forms, supporting documentation is almost entirely absent (84). The intention of this paper has been to demonstrate the key role that the concepts of food preparation and communal dining and their architectural reflections can play in revealing answers to the many questions relating to the monastic and secular settlements in the region. This has certainly the potential to open a new perspective on the subject, given that the typological investigations that to date have focused only on the so-called inverted T-plan would appear to have reached their limits (85).

\section{BIBLIOGRAPHY}

DOĞAN, S. (2008) Alanya ve Çevresinde Erken Hıristiyan - Bizans Evleri ve Kursal Yaşam, Anadolu ve Çevresinde Ortaçă̆ (2) 1-20.

ELLIS, S. (2004) Early Byzantine Housing, Secular Buildings and the Archaeology of Everyday Life in the Byzantine Empire, ed. K. Dark, Oxbow Books, Oxford; 37-52.

EMGE, A. (1990) Wohnen in den Höhlen von Göreme. Traditionelle Bauweise und Symbolik in Zentralanatolien. Ph.D. Dissertation Univ. Heidelberg. Dietrich Reimer Verlag, Berlin.

EYİCE, S. (1996) Observations on Byzantine Period Dwellings in Turkey, Tarihten Günümüze Anadolu'da Konut ve Yerleşme [Housing and Settlement in Anatolia: A Historical Perspective], ed. Y. Sey, İstanbul Historical Foundation, İstanbul; 206-20.

FOSS, C. (1976) Byzantine and Turkish Sardis, Harvard University Press, Cambridge and Mass.

GRISHIN, A. (1989) Byzantine Iconographic Programmes in Cappadocia: The Church of St Barbara in Soğanlı Dere, Phronema (4) 45-51.

GRISHIN, A. (2002) Açı Saray and Medieval Military Campaigns, Our Medieval Heritage. Essays in Honour of John Tillotson for his 60th Birthday, eds. L. Rasmussen, V. Spear and D. Tillotson, Cardiff; 16471.

HILL, S. (1994) When is a Monastery Not a Monastery?, The Theotokos Evergetis and Eleventh-Century Monasticism, Belfast Byzantine Texts and Translation 6.1, eds. M. Mullet and A. Kirby, The Queen's University of Belfast, Belfast; 137-45.

JENSEN, R. M. (2008) Dining with the Dead: From the Mensa to the Altar in Christian Late Antiquity, Commemorating the Dead. Texts and Artifacts in Context. Studies of Roman, Jewish and Christian Burials, eds. R. Saller, L. Brink and D. Green, Walter de Gruyter, Berlin and New York; 107-44.

JERPHANION, G. de (1925-42) Une Nouvelle Province de l'Art Byzantine: Les Églises Rupestres de Cappadoce, 4 vols., Librairie Orientaliste Paul Geuthner, Paris. 
JOHNSON, M. J., TALBOT, A-M. (1991) Monastery, The Oxford Dictionary of Byzantium, Oxford University Press, New York and Oxford; 13912.

JOLIVET-LÉVY, C., DESMESNIL N. L. (2009) Un établissement monastique rural près du village Bahçeli (Cappadoce), Archaeology of the Countryside in Medieval Anatolia. PIHANS 113. eds. T. Vorderstrasse and J. Roodenberg, Leiden; 86-107.

KALAS, V. (2000) Rock-Cut Architecture of the Peristrema Valley: Society and Settlement in Byzantine Cappadocia, unpublished Ph.D. dissertation, New York University, New York.

KALAS, V. (2004) Early Explorations of Cappadocia and the Monastic Myth, Byzantine and Modern Greek Studies (28) 101-19.

KALAS, V. (2005) The 2004 Survey at Selime-Yaprakhisar in the Peristrama Valley, Cappadocia, 23. Araştırma Sonuçları Toplantısı, Antalya; 25366.

KALAS, V. (2007a) The 2004 Survey of the Byzantine Settlement at SelimeYaprakhisar in the Peristrema Valley, Cappadocia, Dumbarton Oaks Papers (60) 271-93.

KALAS, V. (2007b) Cappadocia's Rock-Cut Courtyard Complexes: A Case Study for Domestic Architecture in Byzantium, Housing in Late Antiquity: From Palaces to Shops. Supplementary Volume to Late Antique Archaeology 3.2., eds. L. Lavan, L. Özgenel and A. Sarantis, Brill, Leiden; 393-414.

KALAS, V. (2009a) Challenging the Sacred Landscape of Byzantine Cappadocia, Negotiating Secular and Sacred in Medieval Art, eds. A. Walker and A. Luyster, Ashgate, Aldershot; 147-73.

KALAS, V. (2009b) Sacred Boundaries and Protective Border: Outlying Chapels of Middle Byzantine Settlements in Cappadocia, Sacred Landscapes in Anatolia and Neighboring Regions, BAR International Series, eds. C. Gates, J. Morrin and T. Zimmermann, Oxford; 79-91.

KALAS, V. (2009c) Middle Byzantine Art and Architecture in Cappadocia,The Ala Kilise in Belisirma in the Peristrema Valley, Studies in Honor of Thomas F. Mathews, eds. J. D. Alchermes, H. C. Evans and T. K. Thomas, Philipp von Zabern, Mainz; 184-94.

KALAS, V. (2009d) The Byzantine Kitchen in the Domestic Complexes of Cappadocia, Archaeology of the Countryside in Medieval Anatolia, PIHANS 113, eds. T. Vorderstrasse and J. Roodenberg, Leiden; 109127.

KARPOZILOS, A., KAZHDAN, A., CUTLER, A. (1991) Tables, The Oxford Dictionary of Byzantium, Oxford University Press, New York and Oxford; 2003-4.

KAZHDAN, A. (1991) Furniture, The Oxford Dictionary of Byzantium, Oxford University Press, New York and Oxford; 809.

KAZHDAN, A., JOHNSON, M. J. (1991) Trapeza, The Oxford Dictionary of Byzantium, Oxford University Press, New York and Oxford; 2109.

KOSTOF, S. (1972) Caves of God: The Monastic Environment of Byzantine Cappadocia, MIT Press, Cambridge, Mass. and London. 
KOSTOF, S. (1989) Caves of God: Cappadocia and its Churches, Oxford University Press, New York and Oxford.

KUBAN, D. (1995) The Turkish Hayat House, MTR, Istanbul.

LUCAS, PAUL (1712) Voyage du Sieur Paul Lucas Fait par Ordre du Roy dans la Grèce, l'Asie Mineure, la Macedoine et l'Afrique, 2 vols., Chez Nicolas Simart, Paris.

LUCAS, PIERRE (2003) Les Établissements Monastiques de la Basse de Vallée Göreme at de ses Abords, Dossiers d'Archéologie Mystérieuse Cappadoce (283) 32-41.

MANGO, C. (1976) Byzantine Architecture, New York.

MANGO, C. (1980) Byzantium: The Empire of the New Rome, Scribner, New York.

MATHEWS, T. F., DASKALAKIS-MATHEWS, A. C. (1997) Islamic-Style Mansions in Byzantine Cappadocia and the Development of the Inverted T-Plan, Journal of the Society of Architectural Historians (56:3) 294-315.

OIKONOMIDÈS, N. (1990) The Contents of the Byzantine House from the Eleventh to the Fifteenth Century, Dumbarton Oaks Papers (44) 205-14.

ORLANDOS, A. (1927) Monastiriake Architektonike, Athens.

OUSTERHOUT, R. (1996a) An Apologia for Byzantine Architecture, Gesta 25 (1) 21-33.

OUSTERHOUT, R. (1996b) The 1994 Survey at Akhisar-Canli Kilise, 13. Araştırma Sonuçları Toplantısı; 165-80.

OUSTERHOUT, R. (1997a) Questioning the Architectural Evidence: Cappadocian Monasticism, Work and Worship at the Theotokos Evergetis 1050-1200, eds. M. Mullett and M. Kirby, Belfast; 420-31.

OUSTERHOUT, R. (1997b) Secular Architecture, The Glory of Byzantium: Art and Culture of the Byzantine Era, A.D. 843-1261, eds. H. Evans and W. Wixom, The Metropolitan Museum of Art, New York; 193-9.

OUSTERHOUT, R. (1997c) Survey of the Byzantine Settlement at Çanlı Kilise in Cappadocia: Results of the 1995 and 1996 Seasons, Dumbarton Oaks Papers (51) 301-6.

OUSTERHOUT, R. (2005a) A Byzantine Settlement in Cappadocia, Dumbarton Oaks Studies 42, Dumbarton Oaks Research Library and Collection, Washington, DC.

OUSTERHOUT, R. (2005b) The Ecumentical Character of Byzantine Architecture: The View from Cappadocia, Byzantium as Oecumene, National Research Foundation, Athens; 211-32.

OUSTERHOUT, R. (2010) Remembering the Dead in Byzantine Cappadocia: The Architectural Settings for Commemoration, Architecture of Byzantium and Kievan Rus from the 9th to the 12th Centuries, Materials of the International Seminar, November 17-21, 2009, The State Hermitage Publishers, St. Petersburg; 89-100.

ÖZTÜRK, F. G. (2009) Kapadokya'da Dünden Bugüne Kaya Oymacılığı [Rock Carving in Cappadocia From Past to Present], Arkeoloji ve Sanat Yayınları, Istanbul. 
ÖZTÜRK, F. G. (2010) A Comparative Architectural Investigation of the Middle Byzantine Courtyard Complexes in Açısaray - Cappadocia: Questions of Monastic and Secular Settlement, unpublished Ph.D. dissertation, Middle East Technical University, Ankara.

PEKER, N., UYAR T. (2010) Güzelöz-Başköy ve Çevresi Bizans Dönemi Yerleşimleri 2009, 28. Araştırma Sonuçları Toplantısı (1), T.C. Kültür ve Turizm Bakanlığı; 283-302.

POPOVIĆ, S. (1998) The ‘Trapeza' in Cenobitic Monasteries: Architectural and Spiritual Context, Dumbarton Oaks Papers (52) 281-303.

POPOVIĆ, S. (2007) Dividing the Indivisible: The Monastery Space- Secular and Sacred, Recueil des travaux de l'Institut d'études byzantines (44) 4765 .

RHEIDT, K. (1990) Byzantinische Wohnhäuser des 11. bis 14. Jahrhunderts in Pergamon, Dumbarton Oaks Papers (44) 195-204.

RHEIDT, K. (1996) City or Village? Housing and Settlement in Middle and Late Byzantine Anatolia, Tarihten Günümüze Anadolu'da Konut ve Yerleşme [Housing and Settlement in Anatolia: A Historical Perspective], ed. Y. Sey, İstanbul Historical Foundation, İstanbul; 221-33.

RODLEY, L. (1985) Cave Monasteries of Byzantine Cappadocia, Cambridge University Press, Cambridge.

SIGALOS, L. (2004) Middle and Late Byzantine Houses in Greece, Secular Buildings and the Archaeology of Everyday Life in the Byzantine Empire, ed. K. Dark, Oxbow Books, Oxford; 53-81.

STEA, D., TURAN M. (1993) Placemaking: Production of Built Environment in Two Cultures, Avebury, Aldershot, England and Brookfield, Vermont.

TANYELİ, U. (1996) Housing and Settlement Patterns in the Byzantine, Pre-Ottoman and Ottoman Periods in Anatolia, Tarihten Günümüze Anadolu'da Konut ve Yerleşme [Housing and Settlement in Anatolia: A Historical Perspective, ed. Y. Sey, İstanbul Historical Foundation, İstanbul; 405-71.

TETERIATNIKOV, N. B. (1996) The Liturgical Planning of Byzantine Churches in Cappadocia, Orientalia Christiana Analecta 252, Pontificio Istituto Orientale, Rome.

THIERRY, N. (1984) Découvertes à la nécropole de Göreme (Cappadoce), Comptes-rendus des séances de l'Académie des inscriptions et belles-lettres (128:4) 656-91.

THIERRY, N. (1987) La nécropole de Göreme, Dossiers Histoire et Archéologie (121) 50-5.

TÜTÜNCÜ, F. (2008) The Land of Beautiful Horses: Stables in Middle Byzantine Settlements of Cappadocia, unpublished M.A. thesis, the Department of Archaeology and History of Art, Bilkent University, Ankara. 
Alınd1: 24.08.2011, Son Metin: 06.12.2011

Anahtar Sözcükler: Bizans manastırları; Bizans yerleşimleri; Bizans Kapadokyası; Kapadokya; kaya mimarisi; trapeza'li manastırlar; avlulu manastırlar; avlulu kompleksler/ konutlar; Bizans'ta mutfak yapısı; Bizans yemekhanesi; Orta Bizans; trapezai; triclinia; refrigeria.

\section{KAPADOKYA'DA MUTFAKLARLA YEMEKHANELERİN BEKLENILENIN AKSINNE BİRBİRINDEN AYRI OLMA DURUMU: BİR MIMMARLIK TARİHI MUAMMASI}

Kayadan oyulmuş uzun bir masa (trapeza) ve bankların bulunduğu yemekhane ile yine kayadan oyulmuş devasa koni bir bacanın şekillendirdiği mutfak bir arada olması beklenilen iki mekândır; ancak Kapadokya'da birbirinden ayrı olduklarını görüyoruz. Diğer bir deyişle, bölgede hem bahsi geçen yemekhaneyi hem de özgün mutfağı bünyesinde barındıran kayadan oyma bir yerleşmeye neredeyse hiç rastlanmıyor. Genel olarak, araştırmacılar yemekhanenin bulunduğu yerleşmeleri manastır olarak tanımlamakta ve bunları trapeza'lı manastırlar olarak adlandırmaktadırlar. Gerçekten de, masanın uç kısmına oyulan ve görünüşe bakılırsa başkeşişin yerine işaret eden nişle, Kapadokya yemekhaneleri sıklıkla bu yerleşmelerin monastik kimliği üstüne başlıca argüman olarak ele alınmaktadır. Diğer taraftan, büyük koni bacaların tavanını oluşturduğu ve ocakların duvarlara oyulmuş olduğu mutfakların bulunduğu yerleşmelerde toplu yemek yemeye işaret eden herhangi bir kayaya oyulmuş nesneye rastlanmamaktadır. Bunun yerine, bu yerleşmeler merkezlerinde kimi zaman apsisli büyük salonlara sahiptirler. Dahası bu yerleşmelerin bazıları Roma triclinium' 'unu anımsatan çok apsisli ikinci bir salon daha barındırmaktadır. İlginçtir ki, bu mutfaklı yerleşmeler bazı araştırmacılar tarafından farklı bir manastır tipolojisi olarak kabul görürken diğerleri tarafından da yerel aristokratların konutları varsayılmaktadır. Bu nedenle de, bunların bahsi literatürde savunulan işleve göre avlulu manastırlar ya da avlulu kompleksler/ konutlar olarak geçmektedir. Adından da anlaşılacağı üzere her iki durumda da asıl vurgu mekânların bir avlu çevresindeki düzenindedir. Bu makale, önerilen işlevlerden bağımsız olarak her ikisi de 10.-11.yüzyıllara tarihlenen yemekhaneli ve mutfaklı yerleşmeleri farklı bir bakış açısından; yiyecek hazırlanması ve toplu yemek durumuna odaklanarak, yeniden ve birlikte ele almaktadır. Bu bağlamda, Kapadokya ve dışından, inşa edilmiş ve kayaya oyulmuş trapeza ve mutfak örnekleri karşılaştırmalı olarak incelenmektedir. Sonuç olarak, bu makale bu iki farklı tipolojinin seküler ve monastik özelliklerini ve birbiriyle ilişkisini sorgulamaktadır.

FATMA GÜL ÖZTÜRK; Dipl. Ing. Arch.; Ph.D.

Graduated from Universität Stuttgart, Department of Architecture (2000); received a Ph.D. in Architectural History Program from METU (2010). Her Ph.D. thesis won a Mustafa Parlar Education and Research Foundation Award for the 2009-2010 Academic Year. Worked as practicing architect in Germany and Turkey from 2000 to 2006; and as a Research Assistant at Başkent University, Department of Interior Architecture and Environmental Design from 2006-2009. Currently employed as an instructor at Çankaya University, Department of Interior Architecture. Research interests include; Cappadocia, Byzantine architecture, rock-cut architecture, medieval domestic architecture and medieval settlements.gulozturk@cankaya. edu.tr; fgulozturk@gmail.com 